\title{
LITERACY AND IMPROVED LIVING IN NIGERIAN COMMUNITIES
}

\author{
Adedokun, M.O (Ph.D.), Kayode, G.M \\ Department of Adult Education and Community Development, \\ Faculty of Education, Ekiti State University, Ado-Ekiti \\ E-mail: mary.adedokun@eksu.edu.ng \\ DOI: $10.31364 / S C I R J / v 7.18 .2019 . P 0819 X X$ \\ http://dx.doi.org/10.31364/SCIRJ/v7.i8.2019.P0819XX
}

Abstract: Education is a vital tool for development because it is a life-long process. Education whether formal, informal or non-formal is germane to development and improved living. Education, with which literacy is essentially associated can lead to improved living both on a personal basis and on the community level. This is a fact when education is viewed not only as a social service but a transformative act that is fundamental to people as well as community development as it expands people's knowledge base. Literacy, which used to be traditionally defined as the ability to read, write and calculate has drastically left this stage as the world is globally technologically driven and bearing in mind that literacy is man's capacity to expand his own consciousness in a bid to exercise his power over himself, his environment and his society at large. Literacy has also been internationally identified both as human right and a crucial instrument for the personal pursuit of other rights. This paper ,therefore, addresses the importance of literacy acquisition in a bid to meet the needs of all to achieve improved living, self esteem, empowerment, creativity, critical reflection and to access vital information needed for self growth and community development. The author recommends among others that literacy should be accompanied by technology in this technological driven age, that the Federal Government of Nigeria should desist from emphasising formal education but should fund non-formal education to enable every person have access to education. Individuals too must be willing to become literate to overcome poverty.

Key words: Education, literacy, development, improved living, poverty alleviation.

\section{Introduction}

Literacy as viewed by several authors is an important tool for development. This is why it cannot be tied to its traditional meaning of being the ability to read, write and do some calculations. Literacy has assumed a position of importance as it is through it that development can be accelerated and poverty alleviated so that people can enjoy improved quality of life. Literacy is useful both at the individual and community levels as the benefits accruing to individuals and societies from literacy are manifold. It is a strong key to improved self esteem, empowerment, creativity and critical reflection which are all very vital to improved living. The importance of literacy cannot be over-emphasised. The essence of literacy lies in its importance to everyday event such as improvement in access to health facilities. Literacy, builds a total person through exposure to treasures of knowledge in all facets of life.

Literacy skills are needed by everyone in every place of work, hence every job has specified literacy skills demand in order for persons to qualify for such; hence, there is need for the application of specific literacy skills for processing job related information. Technology is changing and there is wide spread use of information technology which changes the expectations of what the educated person must know and be able to do so as to participate effectively in society. (Grisham 2001). This implies that 
literacy produces desired goals because functional literacy is achievement and occupation oriented. Literacy is, therefore, very important in the total development of a person because it touches all the aspects of a person's life.

\section{Education}

Education is an all encompassing tool for development. It is the foundation of peace, tolerance and a healthy civil society. (UNESCO 2012). Making any reasonable progress for the achievement of developmental goals as stated worldwide would then depend on the level of accessibility of education to all.

UNESCO (2011) reiterates that education is important in reducing poverty, and it is important in improving nutrition and that with education people are less vulnerable to health risks. This document states that educated people are more likely to understand, support, create solutions that ensure development of sustainable cities and communities, use water more judiciously and efficiently and also recycle wastes to bring in more resources not only to household but with funds realised from such, taxes are paid which eventually lead to the development of societies. It is, therefore, imperative that education should be made accessible to all if economies are to improve, if healthy citizens are to be produced and productivity in all areas of life is to be ensured. Various challenges pervade the society especially in the developing world, and this is why literacy which is a strong offshoot of education must be given priority so as to address economic gap, social inequality, environmental problems and bridge the culture of silence which exists between the poor and the rich. Making efforts to bridge these gaps involve making frantic efforts by the government and non-governmental organizations and literate individuals alike to make every citizen acquire information and literacy skills through which they will access needed and useful information that would lead to improvement in all they do. This is germane to making growth and development sustainable both in individuals and in any nation of the world.

Eyong (2016) sums up the importance of access to information by stating that any desired sustainable growth of any nation may be a mirage if its citizens lack information literacy skills. Robbinson-Pant (2014) in Adedokun (2018) conceptualises literacy as a response to increasing awareness of mental sustainability which is likely to solve every problem encountered in the course of living, because the extended meaning of literacy has encapsulated problem solving skill and working in teams. Literacy, therefore, is an encompassing word that is linked to life improvement in the area of economic generation, social activities and political engagements.

Literacy which is an integral part of education serves the purpose of developing in individual the knowledge and skills required for national development and improved standard of living. (Adedokun, 2018). Ayodele and Adedokun (2012) state that education is not only a social service but a transformative act that is fundamental to people as well as community development, this is because education expands people's knowledge base through exposure to the world which can be achieved through access to information. The expansion of knowledge base helps people to shape their destinies and help them move towards desirable goals and better living.

Omolewa (2006) in Adedokun (2008) believes that adult literacy, adult basic and continuing education are key tools to address global challenges in such areas as democracy, peace, learning for sustainability, conflict resolution and work force development. Education in all its forms is thus, vital to improved living. This implies that literacy is basic to every achievement towards improved standard of living as inherent in being literate is "man's capacity to expand his own consciousness in a bid to exercise his power over himself, environment and his society at large". (Ayodele and Adedokun 2012). Education is the medium through which a society can grow and it is a tool through which literacy for all can be achieved. 
One of the goals of the national Policy on Education is total integration of the individual into the immediate community, the Nigerian society and the world. (NPE,2013). This implies that for everyone to be able to participate actively in the affairs of the world, such a person needs to attain some level of literacy. Literacy is, therefore, germane for sustainable development since it aids participation at a greater level in the labour market, thus, reducing poverty level, leading to improved health and to expansion of life opportunities. This implies that when illiteracy will hinder functionality and limit the contributions of individuals to personal growth and the development of their immediate communities, literacy will enhance functionality and people's growth and the growth of the community. Education, therefore, remains the only veritable tool needed to achieve literacy.

It is no doubt that several efforts are being made towards improving education and to make it accessible to all, both at the formal, nonformal and informal levels. Olojede, Adekunle and Samuel (2013) acknowledge the fact that several investments are being put on education; but that in spite of these efforts, literacy level still remains at $60 \%$ of the total population. These authors also believe that the rural population suffers poor literacy rate despite the fact that rural areas house the majority of the nation's population.

Also in an overview of literacy situation in Nigeria by the United Nations International Children Emergency Fund (UNICEF 2018), various issues were exposed, the solution of which could come from literacy. Some of these revealed issues are:

- that Nigeria possesses a stark dichotomy of wealth and poverty. It is believed that though Nigeria is rich in natural resources, its economy is yet to meet the basic needs of people.

- that in spite of the country's vast oil wealth, the majority of Nigerians are poor with 7/10 of the population living on one dollar $(\$ 1.00)$ a day and $92 \%$ on less than two dollars $(\$ 2.00)$ a day.

- that the 2007 United Nations Human development Index ranks Nigeria $158^{\text {th }}$ out of 177 countries which indicates a significant decrease in its human capital as against its being ranked 151 in 2004.

- that poverty still remains one of the most critical challenges facing the country and population growth rates- (which implies a steady increase in the number of the poor).

- that years of military dictatorship, corruption, political instability and poor governance have meant insufficient investments in the country's infrastructure and basic services.

- that health care and general living conditions in Nigeria are poor especially for children and women.

- infant and under-five mortality rates are high.

- HIV/AIDS remains a major issue of concern among children in Nigeria with a prevalence rate of $4.4 \%$. An estimated 2.9 million Nigerians (mostly females are living with the virus). The epidemic due to its wide spread and claiming lives of victims daily is also increasing the population of orphans of the country which according to UNICEF (2018) is estimated at seven (7) million.

This revealed facts pose a great challenge to improved living both at the individual level and at the community or national level. The document also reveals that Nigerian educational system is in a state of neglect largely due to decaying institutional infrastructure. This fact reveals one of the main reasons while the Academic Staff Union of Universities (ASUU) embarked on a prolonged strike from November 4, 2018 till February, 2019.

The document reveals that various institutions were put in place to solve the problem of poverty; a problem that is closely associated with lack of literacy skills, such include the Federal Government's Scheme of National Economic Empowerment and Development Strategies (NEEDS) in 2004 and the elements of which are re-orienting values, reducing poverty, creating wealth and generating employment. For these lofty ideas to become realities, literacy must be entrenched in Nigerian societies, it is then that 
appreciable progress can be made in poverty reduction and people can enjoy improved quality of life as each person will better understand the importance of better utilization of available resources to generate wealth for personal as well as community development.

Fasokun and Pwol (2008) also note that illiteracy still continues to be a significant problem in Nigeria. They also observe that literacy by definition is still narrowed down to mean the ability to read, write and calculate and it is usually thought of as a process for older adults alone. Until literacy is understood to mean having the ability for problem solving and critical thinking which are skills necessary to bring about positive changes needed in individuals and the nation; then literacy efforts will remain at its lowest ebb and one that will not make any meaningful impact on the people and the nation as a whole.

Literacy has been re-defined to bring it to better perspective. The re-definition was the combined efforts of the Persepolis Declaration of 1975, the Vienna Declaration of 1993 and the Hamburg declaration of 1997. Literacy, through all these declarations has been internationally identified both as a human right and as a crucial instrument for the pursuit of other rights. (Fasokun and Pwol,2008). Literacy thus, has a strong role to play in liberating people from the grip of oppression and poverty.

Fasokun and Pwol going by the 2008 global monitoring report, disclose that the most recent data for Nigeria on adult literacy shows that adult literacy rate is put at $69 \%$. The report also indicates that more than 22 million people are illiterate, $65 \%$ are women. Many people do not have access to education because policies are neither concise nor accurate. It is however, the opinion of Adelore and Odiaka (2018) that literacy acquisition is necessary to meet the needs of everybody in a developing country like Nigeria. Meeting those needs include the economic, social, political and environmental needs. Literacy acquisition, thus, produces a total person, one that is able to think and make use of the literacy skills to solve any encountered problem in daily living.

The only way to make Nigerian communities stronger and healthier is to make people literate. When people are literate, they will be able to make personal decisions that will help them rise above poverty level, thereby, stopping them being at the receiving end of the wealthy circle. The poor make the majority of the country, it is, therefore, necessary to become smarter in issues of informed decision making which can only be achieved with functional literacy.

Illiteracy has led several people into illegal migration in a bid to seek improved standard of living. Majority of them were tricked into illegal travelling because they could not decipher between the truth and the lie. This led to many of them dying, many contacting diseases and thus, facing shame.

\section{Hindrances to Literacy}

The first and major hinderance to literacy lies in its definition. Nigeria still operates within a narrow definition of literacy being the ability to read, write and calculate. This definition leaves much to be desired in a high scientific and technological age. Literacy is about its functionality in bringing solutions to identified problems through critical thinking.

Omolewa (2018) highlighting failures of past efforts on literacy states that efforts to propagate literacy in Nigeria had met with failures because literacy as important as it is, has always been ignored in the sense that it has always been poorly funded and not being given appropriate position as a tool useful in the process of development. 
Basic literacy (both formal and non-formal) is being hindered by many factors such as learning environment that is not conducive, insufficient classrooms and with inadequate equipment, and insufficient teachers among others.

Fasokun and Pwol (2008) also enumerated some of the challenges facing literacy. Such challenges include:

- problem in primary education which is evident in low enrolment rates (which may be due to poverty on the part of parents), high dropout rates which is also not unconnected with poverty as some parents find it very difficult to provide simple school needs for their children.

- inadequate facilities at school, poor teaching/learning materials and irrelevant curriculum.

- poor enrolment rates in adult education programme. Adults, in making efforts to make ends meet find it difficult to enrol in adult education that will lead them to being literate. Adults also drop out if they think the programme has no relevance to their daily activities.

- the exclusion of women from adult education programme also limit the level of literacy.

- literacy instructors are not usually well trained in facilitation skills. This leads to poor delivery in literacy classes and leaners might be eventually discouraged from attending such classes.

- Poor access to adult education for communities that are not easily reachable such as nomadic and fishing communities.

- Failure to sustain literacy rates due to poor resources including equipment, teachers and most importantly, the negative perceived value of education by Nigerians; the attitude of which is "those who had education have no rewarding jobs, so of what value is education".

Among others, Fasokun and Pwol identified poor literate environment as that environment that does not maintain literacy skills in the long run. If literacy skill is not maintained, it is forgotten and, therefore, of no value to personal development and the nation.( Omolewa ,2018).

- $\quad$ Lack of political will to make illiteracy a forgone issue by allocating adequate funds to it is another major identified challenge.

\section{Literacy and Improved Living}

To Omolewa (2018), literacy is the foundation for all further learning and it is the cornerstone of Education for All (EFA), the Millennium Development Goals and the sustainable Development Goal 4. The above shows that literacy is the foundation of improved living in any society, Nigeria inclusive.

Ayodele and Adedokun (2012) enumerate the importance of literacy as it is linked to improved living standard. They submit that:

- Being literate will help people tackle any problem they are faced with.

- Literacy provides positive change in individuals which transcends to change in communities, societies and nations at large.

- Literacy is a source of providing opportunities to go higher in the ladder of development.

- Being literate increases the efficiency and effectiveness of individuals in the performance of their daily assignments.

The above reflect the fact that literacy has roles to play in every area of human endeavour. Literacy is germane to productivity in every sector of the economy especially among the peasant rural farm families. With literacy, farmers would attend seminars, access information that would lead to improvement in agricultural production. This Akotunola (2015) believes would be a 
viable alternative to criminal activities as sources of earning a living. Emphasising on the benefit of literacy in promoting good living; Omolewa (2018) submits that:

"Literature shows the benefit of literacy to the promotion of justice, employment drive, good driving, better farming, informed politics and good marketing"

The above implies that making efforts to remove impediments to literacy will lead to improved standard of living.

There are various impediments to good living in Nigeria. These include; limited access to services such as schools, health centres and access to safe drinking water. Others include inability to market agricultural products adequately due to lack of rural roads which make market products spoil easily; there are no new technology for farming which keeps farm yields very low. There is the problem of drought, erosion and oil pollution and lack of informed political participation. The solution to all these problems lies in literacy. All the stated problems above manifest in poor living and inability to give voice to one's feeling.

Various authors who had worked on literacy are of the opinion that solution to every encountered problem lies in education. The United Nations Educational Scientific and Cultural Organization (UNESCO) in Adedokun (2018) attach great importance to literacy. The body views the acquisition of literacy skills as an intrinsic part of the right to education with the aim of empowering people and enabling them to participate fully in societies. Through literacy, informed decisions would be made on businesses and on voting. Persson (2013) believes that education and political participation are undoubtedly related.

Literacy would help in critical thinking and enable problem solving ability with the result that solutions would be sought to identified problems. This would be aided with improved ability to use information technology tools to search for required information, thereby making access to the world a simple thing. This will bring improvement to one's life and humanity in general.

Education to which literacy is closely associated is a vital tool for development because it is a life-long process and it is important for development and improved living. Being literate removes the lethargic attitude of people, make them participate actively and reasonably in decisions that positively affect their lives. Being literate is therefore, a key factor in reducing poverty through acquisition of skills that would break poverty cycle. It will make people acquire positive attitudes and values that would lead to improved standard of living.

Literacy will make it possible to access vital information which would lead one to being more innovative. Hyslop-Margison and Welsh (2003) express the need for bridging the skill gap myth and knowledge gap and this can be done when people are literate.

Productivity in every area of human endeavour is limited when one is not literate (Baseline 2001).

\section{Solutions}

The main solution to the problems besetting literacy as proffered by Omolewa (2018) is to look into the past to find solutions to why literacy efforts had not been yielding expected results.

Literacy should be made interesting by reviewing the curriculum of adult education; making such to be in accordance with the needs of individuals enrolling for literacy classes as well as making it to meet the needs of the community. If literacy is to bring improved 
living to people, it must be made practical so that each person would experience fulfilment in undergoing the process of being literate. This means literacy must be closely associated to everything one does.

\section{Observation:}

The researchers observed on two occasions that illiteracy paves way for cheating.

First, a Togolese woman selling cooked beans and yam in Lagos, Nigeria, found calculation so difficult that after selling to her customers, she had to rely on some of these same customers to calculate how much money she would take from them and how much change she would give back to them. This could lead to cheating and shortchanging in her business and though trying to get out of poverty, illiteracy would plunge her deep into it again.

Secondly, one of the researchers was at Bola Ige International Market in Ibadan, Oyo state, Nigeria, where clothes are sold. A wrapper of Ankara was bought for N1,700 and the seller was given N2,000. Because the clothe seller/vendor was an illiterate, she found it difficult to understand what change she would give from N2,000. The buyer was speaking of the money in English while the seller could not understand.

Contrary to the above observations one of the researchers also witnessed an incidence of a woman who bought clothes of $15 y$ ards but in three yards each. The seller cheated on the buyer with fake measurement. After the buyer checked the yards measured for her and found three of the packed clothes not to be complete, she returned them and the seller had to give the ones rightly measured. The above reveal that literacy is key in every aspect of life.

\section{Conclusion}

The above review shows that there is no alternative way to achieving development and improved living without literacy being used as a tool for empowerment and liberation of people. Literacy is fundamental for personal improved living standard and it is equally important for a nation to experience sustainable development. Nigeria, in making literacy a useful tool for improved living, should determine what constitutes literacy so as to make it more practical and more relevant to daily living. Education should, therefore, be made accessible to all to foster development.

\section{Recommendations}

The following recommendations are made:

- Literacy should not be considered as it was of old but must be accompanied by technology so as to make it essentially effective in this age that is technological driven.

- Literacy must be associated with initiatives and innovations that will encourage individuals in Nigerian communities to be self-reliant so as to live above poverty level.

- Government must not only emphasize formal education if truly education is meant to be assessed by all. Education must be made accessible to all in diverse forms to make the best use of their potentials for improvement in standard of living.

- While Nigerian government is taking necessary steps to address living conditions in the country, individuals too must take giant strides towards being literate so as to overcome poverty economically, socially and politically. 
- Every Nigerian should operate in the new realm of the term literacy which is having the problem solving and critical thinking skills necessary to bring about required positive changes that would lead to active citizenship, improved health and livelihood.

\section{References}

Adedokun M.O. (2018). Information literacy for sustainable development in International Journal of Review of Management and Business Research 7 (2)456-462

Adedokun, M.O. (2008). Introduction to Adult Education, Lagos, Honey Crown Educational Publishers.

Adedokun, M.O. (2018). Information literacy and voters education. International Journal of Literacy Education 8(1) Research. 8(1) 190-203

Adelore, O. and Odiaka, I. (2018). Generating Learners content through language experience approach (LEA) for motivating ,retention and persistence in adult literacy programmes International Journal of Literacy Education 8(1) 41-57

Akotunola, B. (2015). Improving Agricultural Productivity through community seed Programme. https://allafrica.com/stories/2015/00/10632.html.

Ayodele J.B and Adedokun M.O (2012). Towards achieving functional and adult literacy in Nigeria. European Scientific Journal 8(5) 209-218

Baseline (2001). A Handbook on Information on basic education in Nigeria. Abuja, UNESCO.

Eyong, I.U. (2016). Information Literacy and National Development in Nigeria. Academix www.academix.ng/search/paper.html?idd=3 300016544. Accessed-20-6-2018

Fasokun, T. and Pwol, C. (2008). DVV International: Nigeria: The current situation within the framework of the International Benchmarks. https://www.dvv- international.de/adult-education-and-development/editions/aed/7/2008/national-andregional-reflections .

Grisham, D.L. (2001). Making technology meaningful for literacy teaching. A webquent. Reading online 4(7). Available: http://www.readingonline.org,editorial/edit- $\quad$ index.asp/HREF=editorial/February2001/index.html.

Hyslop-Margison, E.J. and Welsh, B.H. (2003), Career education and labour market condition. The Journal of Educational Thought. 37 (1) 5-21.

National Policy on Education (2013). $6^{\text {th }}$ edition. Abuja, Educational Research and Development Council

Olojede, A.A., Adekunle, A.A. \& Samuel, E.A. (2013). Analysis of rural literacy as a panacea for socio-economic development of Nigeria. International Journal of Sociology and Anthropology 5(9) 381-390.

Omolewa, M. (2018) Repositioning literacy for sustainable development and empowerment International journal of Literacy Education 8(1) 22-30

Persson, M. (2013). Does education cause participation in politics? https://gupea.ub.gu.se/bitstream/2077/3412//gupea_2077_3412 4.pdf.

UNESCO (2011). Education counts. Towards the Millennium Development Goals. New Updated Edition, Paris.

UNESCO (2012). International Literacy day, 8 September: 2012: Literacy and Peace www.un.org/en/events/literacyday/ Accessed January 10, 2019

UNICEF: Overview - The Nigerian situation (2018). https://www.unicef.org/Nigeria/1971_2199.html. Accessed January 11,2019 
